\title{
Correspondence
}

To the Editors

\section{Breastfeeding and COVID-19 vaccination}

Sri Lanka Journal of Child Health, 2021: 50(3): 567

DOI: http://doi.org/10.4038/sljch.v50i3.9754

(Key words: Breastfeeding, COVID-19 vaccination)

Dear Editors,

COVID-19 vaccine is the new hope for successful COVID-19 containment. The vaccine is recommended and the benchmark is reaching herd immunity level. The interesting group that might receive vaccination is breastfeeding women. The present consideration is on the interrelationship between breastfeeding and COVID-19 vaccination.

Basically, COVID-19 transmission via breastfeeding is not confirmed and there is no contraindication to breastfeeding. Regarding COVID-19 vaccination, usefulness is expected for breastfeeding mothers. Focusing on neonate receiving breastfeeding, antibody is detected in mother receiving mRNA based COVID-19 vaccine and it can confirm the advantage to the neonate ${ }^{1-3}$.

We should also discuss on reported adverse effects of vaccination among lactating mothers and their children. There is no report on adverse effects among breastfed children but adverse effects in lactating mothers are already reported. Rare cases of subacute thyroiditis in lactating mothers are reported and it is necessary to recognize this complication ${ }^{4}$. Finally, an important topic which should be discussed is vaccine hesitancy among lactating mothers. In a recent report, a considerable number of lactating mothers rejected vaccination ${ }^{5}$. It is necessary to prepare an urgent plan for managing COVID-19 vaccine among lactating mothers.

\section{References}

1. Joob, B, Wiwanitkit V. COVID-19 transmission and breastfeeding. Sri Lanka Journal of Child Health 2020; 49:198. https://doi.org/10.4038/sljch.v49i2.8978

2. Sculli MA, Formoso G, Sciacca L. COVID-19 vaccination in pregnant and lactating diabetic women. Nutrition, Metabolism and Cardiovascular Disease 2021 Apr 24: S0939-4753(21)00182-4 https://doi.org/10.1016/j.numecd.2021.04. 012

PMid: 34039507 PMCid: PMC8064812

3. Atyeo C, DeRiso EA, Davis C, Bordt EA, DeGuzman RM, Shook LL, et al. COVID19 mRNA vaccines drive differential Fcfunctional profiles in pregnant, lactating, and non-pregnant women. BioRxiv 2021 Apr 5:2021.04.04.438404. https://doi.org/10.1101/2021.04.04.438404

4. Sutton D, D'Alton M, Zhang Y, Kahe K, Cepin A, Goffman D, et al. COVID-19 Vaccine Acceptance among pregnant, breastfeeding and non-pregnant reproductive aged women. American Journal of Obstetrics and Gynecology MFM. 2021 May 25:100403. Online ahead of print. https://doi.org/10.1016/j.ajogmf.2021.100 403

PMid: 34048965 PMCid: PMC8146275

5. İremli BG, Şendur SN, Ünlütürk U. Three cases of subacute thyroiditis following SARS-CoV-2 vaccine: Post-vaccination ASIA syndrome. Journal of Clinical Endocrinology and Metabolism 2021 May 27:dgab373. doi: 10.1210/clinem/dgab373. Online ahead of print. https://doi.org/10.1210/clinem/dgab373 PMid: 34043800

\author{
*Amnuay Kebayoon ${ }^{1}$, Viroj Wiwanitkit ${ }^{2}$ \\ ${ }^{1}$ Private Academic Consultant, Samraong, \\ Cambodia \\ ${ }^{2}$ Adjunct Professor, Joseph Ayobaalola University, \\ Ikeji-Arakeji, Nigeria; Honorary professor, Dr DY \\ Patil University, Pune, India \\ *Correspondence: amnuaykleebai@gmail.com
}

https://orcid.org/0000-0002-1976-2393 